\title{
Diversity Among Isolates of Bean pod mottle virus
}

\author{
Hongcang Gu, Anthony J. Clark, P. B. de Sá, Todd W. Pfeiffer, Sue Tolin, and Said A. Ghabrial
}

\begin{abstract}
First, second, third, and sixth authors: Department of Plant Pathology, University of Kentucky, Lexington 40546; fourth author: Department of Agronomy, University of Kentucky, Lexington 40546; and fifth author: Plant Pathology, Physiology and Weed Sciences Department, Virginia Polytechnic Institute and State University, Blacksburg 24061.
\end{abstract}

Accepted for publication 21 December 2001.

\section{ABSTRACT}

Gu, H., Clark, A. J., de Sá, P. B., Pfeiffer, T. W., Tolin, S., and Ghabrial, S. A. 2002. Diversity among isolates of Bean pod mottle virus. Phytopathology 92:446-452.

Isolates of Bean pod mottle virus (BPMV), a member of the genus Comovirus, collected from soybean fields in Kentucky, Virginia, Arkansas, and Iowa were classified into two distinct subgroups, I and II, based on nucleic acid hybridization analysis using cloned cDNA probes to RNA-1 from BPMV strains K-G7 and K-Ha1. Slot blot hybridization analysis using cloned cDNA probes to RNA-2 from the same two strains (K-G7 and K-Ha1), however, revealed that some of the isolates, initially classified as belonging to subgroup I after analysis with RNA-1 probes, are in fact natural reassortants between the two strain subgroups. This was corroborated by nucleotide sequence analysis of full-length cDNA clones of both RNA-1 and RNA-2 from a putative reassortant strain (K-
Ho1). These results indicate that BPMV strain diversity is more complex than initially anticipated, and that the use of cloned probes to both genomic RNAs during nucleic acid hybridization analysis is required to unravel the extent of such diversity. In a field plot experiment, BPMV isolates that belong to distinct strain subgroups induced symptoms that varied in severity and in the level of yield losses. In this regard, the reassortant strain K-Ho1 caused the most serious damage compared with four other BPMV isolates tested. Furthermore, the soybean alleles $R s v_{1}$ and $R s v_{4}$, known to confer resistance against Soybean mosaic virus, a member of the genus Potyvirus, did not provide any protection against BPMV. Additionally, we developed a reverse transcription-polymerase chain reaction procedure based on the sequence of a highly conserved region in the capsid polyprotein coding sequence that provides efficient and highly sensitive detection of all BPMV isolates tested, regardless of their strain classification.
Bean pod mottle virus (BPMV) is a member of the genus Comovirus in the family Comoviridae (11). Like other comoviruses, BPMV has a bipartite positive-strand RNA genome consisting of RNA-1 and RNA-2 that are separately encapsidated in isometric particles $28 \mathrm{~nm}$ in diameter. Purified BPMV preparations can be separated by density gradient centrifugation analysis into three sedimenting viral components designated top (T), middle (M), and bottom (B). The T component contains empty particles, whereas the $\mathrm{M}$ and $\mathrm{B}$ components contain single molecules of RNA-2 (approximately $3.6 \mathrm{~kb}$ ) and RNA-1 (approximately $6.0 \mathrm{~kb}$ ), respectively. The three components have identical protein composition consisting of 60 copies each of a large (L) and small (S) coat protein of 41 and $22 \mathrm{kDa}$, respectively. The $\mathrm{S}$ coat protein occurs in two major size classes: the intact protein and a $\mathrm{C}$ terminus-truncated version (15).

BPMV genomic RNAs are polyadenylated and have a small basic protein, viral genome-linked protein (VPg), covalently linked to their $5^{\prime}$ termini. The BPMV genome is expressed via the synthesis and subsequent cleavage of large polyprotein precursors $(11,15)$. The complete nucleotide sequences of the two genomic RNAs of BPMV strain KY-G7 have been reported $(4,16)$. BPMV RNA-1 codes for five mature proteins required for replication (from $5^{\prime}$ to $3^{\prime}$, a protease cofactor [32K], a putative helicase [58K], a VPg, a protease [24K], and a putative RNA-dependent RNA polymerase $[87 \mathrm{~K}]$ ), whereas RNA-2 codes for a putative cell-to-cell movement protein and the two coat proteins $(4,16)$.

BPMV is widespread in the major soybean-growing areas in many of the southern and southeastern United States $(8,12,22,25)$. A recent severe outbreak in BPMV incidence in the North Central and Northern Great Plains states is currently the cause of serious

Corresponding author: S. A. Ghabrial; E-mail address: saghab00@uky.edu

Publication no. P-2002-0218-01R

(C) 2002 The American Phytopathological Society concerns to soybean growers and to the soybean industry in this region (J. Hill, personal communication; S. A. Ghabrial, unpublished data). BPMV is efficiently transmitted in nature, within and between soybean fields, by several species of leaf-feeding beetles in the family Chrysomelidae (mainly the genera Ceratoma and Diabrotica). Beetle vector species also occur in the families Coccinellidae, Curulionidae, and Meloidae $(7,12,20)$. The deleterious effects of BPMV infection are not limited to seed yield but extend to seed quality, because BPMV predisposes soybeans to Phomopsis spp. seed infection (26), a major cause of poor seed quality in soybean (24). Furthermore, BPMV interacts synergistically with Soybean mosaic virus (SMV), a member of the genus Potyvirus, with drastic reduction of yield and seed quality $(1,2,21)$.

Disease management through genetic resistance is not possible at present because no soybean cultivars with resistance to BPMV are commercially available. A limited number of transgenic soybean lines expressing BPMV capsid polyprotein have been produced and were shown to confer protection against BPMV infection $(5,19)$. Such transgenic resistance could be incorporated into commercial varieties. Because of the recent BPMV outbreaks, a concerted effort is currently underway to screen available soybean germ plasm for resistance/tolerance to BPMV infection. No information, however, is available on strain diversity among BPMV isolates. Knowledge of the genetic diversity among BPMV isolates is necessary to ensure that selected or newly developed soybean germ plasms may offer broad protection against the full range of BPMV strains found in nature. In this communication, we report the occurrence of at least two distinct subgroups of BPMV strains that can be clearly distinguished based on nucleic acid hybridization analysis. Furthermore, we present evidence for the occurrence in nature of reassortants between the two strain subgroups. Additionally, we developed a reverse transcription-polymerase chain reaction (RT-PCR) protocol based on the sequence of a highly conserved region in the capsid polyprotein coding 
sequence that provides efficient and highly sensitive detection of all BPMV isolates tested, regardless of their strain classification.

\section{MATERIALS AND METHODS}

Virus isolates. A list of the BPMV isolates used is shown in Table 1 . In most cases, the isolates are designated by the county and the state from which they were originally collected. The various BPMV isolates were propagated in the soybean cv. York or Essex, and infected tissues were used for virion purification as previously described (9). The complete nucleotide sequences of the genomic RNAs from isolates K-G7 $(4,16), \mathrm{K}-\mathrm{Ha} 1$, and K-Ho1 (H. Gu, C. Zhang, and S. A. Ghabrial, unpublished data) have been determined and the sequences have been deposited in GenBank (GenBank accession numbers provided in Table 1). Where appropriate, the well-characterized isolates, K-G7, K-Ha1, and K-Ho1, will be referred to as strains.

Nucleic acid hybridization analysis. Viral RNAs were extracted from purified virions by the sodium dodecyl sulfate (SDS)phenol method of Peden and Symons (18), and assayed by northern hybridization analysis using a cloned cDNA probe to RNA-1 from strain K-G7. Because the ratio of RNA-1 to RNA-2 may vary among virus isolates and to ensure that equivalent amounts of RNA-1 are subjected to northern hybridization analysis, the amounts of total viral RNA loaded per lane were adjusted based on image analysis of scanned gels. For this purpose, images of ethidium bromide-stained gels were generated by a digital imaging system (Alpha Innotech Corporation, San Leandro, CA) and the resulting images were analyzed by the AlphaEase program (Alpha Innotech Corporation) using the 1Dmultiline densitometry tool. The integrated area under the RNA-1 peak was then determined for all the RNA preparations to be tested. The volumes of the RNA samples were adjusted accordingly so that equivalent amounts of RNA-1 were loaded for each BPMV isolate, as demonstrated in Figure 1. For northern hybridization analysis, viral RNA samples from the same preparations used for image analysis and in similar amounts to those shown in Figure 1 (approximately $1.0 \mu \mathrm{g}$ ) were used. The viral RNAs were separated by electrophoresis on $1.5 \%$ formaldehyde agarose gels (23) and transferred onto Hybond $\mathrm{N}^{+}$membranes (Amersham, Piscataway, NJ) according to the manufacturer's instructions. The membranes were then prehybridized for $12 \mathrm{~h}$ at $42^{\circ} \mathrm{C}$ in a solution containing $5 \times \mathrm{SSC}(1 \times \mathrm{SSC}$ is $0.15 \mathrm{M} \mathrm{NaCl}$ plus $0.015 \mathrm{M}$ sodium citrate), $50 \%$ formamide, $0.5 \%$ SDS, and $100 \mu \mathrm{g}$ of salmon sperm DNA per ml. Hybridization to the radiolabeled cloned cDNA

TABLE 1. Sources of Bean pod mottle virus isolates used and year of collection

\begin{tabular}{llc}
\hline $\begin{array}{l}\text { Virus isolate } \\
\text { (GenBank Accession No.) }\end{array}$ & Location & $\begin{array}{c}\text { Year } \\
\text { collected }\end{array}$ \\
\hline A-S98-50M & Kaiser, AR & 1998 \\
I-JH1 & Ames, IA & 2000 \\
K-C1 & Caldwell County, KY & 1997 \\
K-C2 & Caldwell County, KY & 1997 \\
K-D1 & Daviess County, KY & 1998 \\
K-Fa1 & Fayette County, KY & 1996 \\
K-Fu1 & Fulton County, KY & 1987 \\
K-G7 (M62738, U70866) & Graves County, KY & 1975 \\
K-Ha1 (AF394606, AF394607) & Hancock County, KY & 1998 \\
K-He1 & Henderson County, KY & 1998 \\
K-He2 & Henderson County, KY & 1998 \\
K-He3 & Henderson County, KY & 1998 \\
K-Ho1 (AF394608, AF3946080) & Hopkins County, KY & 1998 \\
K-U1 & Union County, KY & 1998 \\
M-D3 & Delta Station, MS & 1997 \\
M-G1 & Greenville, MS & 1997 \\
V-W1 & Warsaw, VA & 1997 \\
V-W2 & Warsaw, VA & 1997 \\
V-S98-1 & Mount Holly, VA & 1998 \\
V-S98-15 & Warsaw, VA & 1998 \\
\hline
\end{tabular}

probes was in the same buffer for $16 \mathrm{~h}$ at $42^{\circ} \mathrm{C}$. The membranes were then washed two times for $10 \mathrm{~min}$ each at room temperature in $2 \times \mathrm{SSC}$ containing $0.1 \%$ SDS, followed by washing two times with $1 \times \mathrm{SSC} / 0.1 \% \mathrm{SDS}$ at room temperature, and two times in $0.1 \times \mathrm{SSC}$ containing $0.1 \% \mathrm{SDS}$ at $65^{\circ} \mathrm{C}$ for $30 \mathrm{~min}$. The membranes were air-dried and exposed to Bio-Max film (Eastman Kodak, Rochester, NY) for 2 to $12 \mathrm{~h}$. For slot blot hybridization analysis, RNA was extracted from purified virions and, after concentration by ethanol precipitation, suspended in $2 \times \mathrm{SSC}$, and spotted onto Hybond $\mathrm{N}^{+}$membranes by a filtration apparatus (Minifold II; Schleicher \& Schuell, Keene, NH). The RNA samples (200 ng, unless otherwise specified) were fixed onto membranes according to the manufacturer's instructions. Procedures and conditions for prehybridization, hybridization, and membrane washings were as described for northern hybridization analysis. The probes were prepared by nick-translation of fulllength cDNA clones of RNA-1 and RNA-2 from isolates K-Ha1, $\mathrm{K}-\mathrm{Ho}$, and K-G7 (except that a partial clone containing nucleotides 1511 to 3117 was used for K-G7 RNA-1). The membranes were then air-dried and exposed to a phosphorimager screen (Molecular Dynamics, Sunnyvale, CA) for 2 to $5 \mathrm{~h}$. The images were visualized by a PhosphorImager 445 SI system and analyzed with the ImageQuant 4.1 program (Molecular Dynamics).

RT-PCR. A pair of primers, a reverse primer (BPCPr; 5'-AGTGGACCATGTGAGAAAC-3') and a forward primer (BPCPf; 5'-ATAGTTCCATTAGAGGGCGTG-3'), was designed to prime the amplification of a conserved region (a fragment of approximately $650 \mathrm{bp}$ ) in the coding region of BPMV capsid polyprotein. RNA was extracted from purified virions of each isolate and was reverse transcribed using Superscript II (Gibco BRL, Gaithersburg, MD) and the reverse primer, BPCPr, followed by treatment with RNase $\mathrm{H}$. The cDNA was subjected to PCR using the forward and reverse primers and DyNAzyme EXT DNA polymerase (Finnzymes Oy, MJ Research, Inc., Waltham, MA). Thermal cycling conditions were $94^{\circ} \mathrm{C}$ for $2 \mathrm{~min}, 35$ cycles of $94^{\circ} \mathrm{C}$ for $1 \mathrm{~min}, 61^{\circ} \mathrm{C}$ for $1 \mathrm{~min}$, and $72^{\circ} \mathrm{C}$ for $2 \mathrm{~min}$, followed by $5 \mathrm{~min}$ at $72^{\circ} \mathrm{C}$. PCR products were cloned into pGEMT-Easy vector (Promega, Madison, WI) and sequenced by cycle sequencing using M13 universal primers, a DNA sequencing kit (Big Dye Terminator; Applied Biosystems, Foster City, CA), and an ABI Prism 310 genetic analyzer. Sequence analysis was performed using the GAP, PILEUP, and PRETTY programs of the University

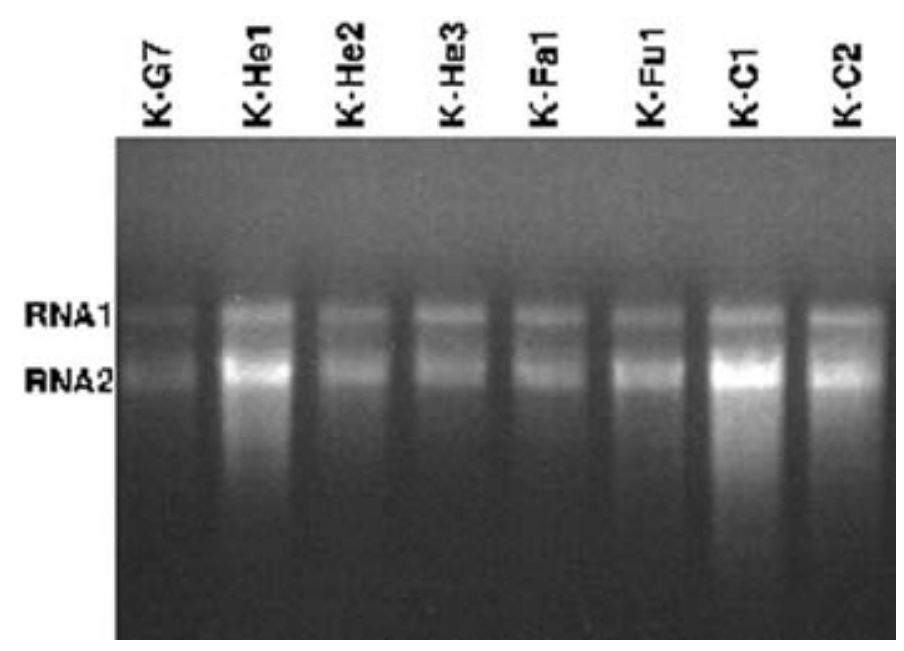

Fig. 1. Agarose gel electrophoresis of purified Bean pod mottle virus (BPMV) RNA. RNA samples from representative BPMV isolates were electrophoresed on $1 \%$ agarose gels and stained with ethidium bromide. The amounts of total viral RNA loaded per lane were adjusted based on prior image analysis of scanned gels of the same RNA preparations so that all lanes contain equivalent amounts of RNA-1. The designations of the BPMV isolates from which the RNAs were isolated are marked at the top of each lane. 
of Wisconsin GCG software package (Genetics Computer Group, Madison, WI).

Western blot analysis. Following SDS-polyacrylamide gel electrophoresis (PAGE) on 12\% polyacrylamide gels (14), the proteins were transferred to an Immobilon-P transfer membrane (Millipore) using a mini Trans-Blot electrophoretic transfer apparatus (Bio-Rad Laboratories, Hercules, CA) at $70 \mathrm{~V}$ for $1 \mathrm{~h}$. The membrane was then incubated overnight at $4^{\circ} \mathrm{C}$ in Tris-buffered saline (TBS; $20 \mathrm{mM}$ Tris- $\mathrm{HCl}$ buffer containing $150 \mathrm{mM} \mathrm{NaCl}$, $\mathrm{pH}$ 7.4) containing 5\% non-fat milk and incubated at room temperature for $2 \mathrm{~h}$ with an antiserum to BPMV virions (10) diluted

TABLE 2. Host reactions to representative Bean pod mottle virus isolates collected from four states

\begin{tabular}{|c|c|c|c|c|}
\hline Isolate & $\begin{array}{c}\text { Strain } \\
\text { subgroup }^{\mathrm{w}}\end{array}$ & $\begin{array}{l}\text { Soybean } \\
\text { 'Essex'x }\end{array}$ & $\begin{array}{c}\text { Cowpea } \\
\text { 'Blackeye'y }\end{array}$ & $\begin{array}{c}\text { Chenopodium } \\
\text { quinoa }^{\mathrm{z}}\end{array}$ \\
\hline A-S98-50M & II & M & SL (+) & CL $(+)$ \\
\hline $\mathrm{K}-\mathrm{C} 1$ & II & I & SL (+) & CL \\
\hline $\mathrm{K}-\mathrm{C} 2$ & I/II & I & SL (+) & CL \\
\hline K-D1 & II & M & SL (+) & CL \\
\hline K-Fa1 & II & M & SL (+) & CL \\
\hline K-Fu1 & I/II & $\mathrm{S}$ & $\mathrm{SL}(+)$ & CL \\
\hline K-G7 & I & I & $\mathrm{SL}(+)$ & CL \\
\hline K-Ha1 & II & M & $\mathrm{SL}(+)$ & CL \\
\hline K-He1 & II & M & $\mathrm{SL}(+)$ & CL \\
\hline K-He2 & II & M & SL (+) & CL \\
\hline K-He3 & II & I & SL (+) & CL \\
\hline K-Ho1 & I/II & $\mathrm{S}$ & Mo & CL \\
\hline K-U1 & I/II & I & SL (+) & CL \\
\hline M-D3 & II & M & $\mathrm{SL}(+)$ & RS, LP \\
\hline M-G1 & II & M & SL (+) & RS, LP \\
\hline V-S98-1 & I & M & $\mathrm{SL}(+)$ & CL (+) \\
\hline V-S98-15 & II & M & $\mathrm{SL}(+)$ & RS, LP \\
\hline V-W1 & II & M & SL (+) & RS \\
\hline V-W2 & II & M & SL & RS, LP \\
\hline
\end{tabular}

${ }^{\text {w }}$ Strain subgroup affiliation (I, II, or an assortment I/II) was determined by nucleic acid hybridization analysis (Figs. 2 to 5).

${ }^{\mathrm{x}} \mathrm{M}=$ mild (green mottling with little or no stunting/blistering); $\mathrm{I}=$ intermediate (green/yellow mottling, some stunting, leaf distortion, and blistering); $\mathrm{S}=$ severe (yellow mottling, severe stunting, blistering, and necrosis on inoculated leaves).

${ }^{y} \mathrm{SL}=$ symptomless; $(+)=$ noninoculated upper leaves are enzyme-linked immunosorbent assay positive; $\mathrm{Mo}=$ mosaic.

${ }^{\mathrm{z}} \mathrm{CL}=$ chlorotic lesions; $\mathrm{RS}=$ ring spots; $\mathrm{LP}=$ line patterns.
1:2,000 in $1 \times \mathrm{TBS} / 5 \%$ nonfat milk. The membrane was washed twice in water and three times in $1 \times$ TBS, and reacted with the secondary antibody, goat anti-rabbit immunoglobulin G conjugated with alkaline phosphatase (Sigma-Aldrich, St. Louis) (diluted 1:2,000 in $1 \times$ TBS containing 5\% nonfat milk) for $1 \mathrm{~h}$ at room temperature. Following washing as described previously, the bound antibody was detected using 5-bromo-4-chloro-3-indolyl phosphate $p$-toluidine salt and $p$-nitro blue tetrazolium (Promega) as substrates.

Field studies. A field plot experiment was carried out in 1999 to study the effects of infection with each of five different isolates of BPMV (K-G7, K-Ha1, K-Ho1, K-D1, and K-U1) on soybean yield. The selected BPMV isolates differ in the severity of the symptoms they induce in soybean from mild to severe (Table 2). Three Essex isolines (Essex, Essex-Rsv $v_{1}$, and Essex-Rsv provided by G. Buss, Virginia Polytechnic Institute \& State University), which differ in the presence of resistance genes to SMV, were inoculated with the five BPMV isolates. Inoculum for each isolate was prepared by extracting infected leaf tissue with $0.05 \mathrm{M}$ potassium phosphate buffer, $\mathrm{pH} 7.0$ (1:10, wt/vol). Young leaves from Essex soybean seedlings infected with the individual BPMV isolates (2-weeks postinoculation) were used as sources of inoculum. Carborundum (600-mesh) was added to the inoculum prior to application.

The experiment was conducted as a completely randomized design. Each virus-isoline combination was replicated three times. Each isoline was included as a noninoculated control three times. The experiment was planted on 24 May, and all plants in a plot were rub-inoculated with sap from infected soybeans on 17 June at growth stage V2/V3 as described previously (6). Each plot consisted of six plants spaced 2 inches apart in a hill, with hills spaced 30 inches apart. The plots were sprayed every other week with Malathion in an attempt to reduce the spread of BPMV by bean leaf beetles to noninoculated plants in control plots. Viruslike symptoms were first detected on noninoculated control plants on 29 July. Because these symptoms appeared on all three isolines, we judged them not to be the result of SMV. The experiment was irrigated five times (approximately every 2 weeks) from the middle of July to early September.

Yield (gram per plot) was measured on each six-plant hill plot. The yield data were analyzed by analysis of variance and linear

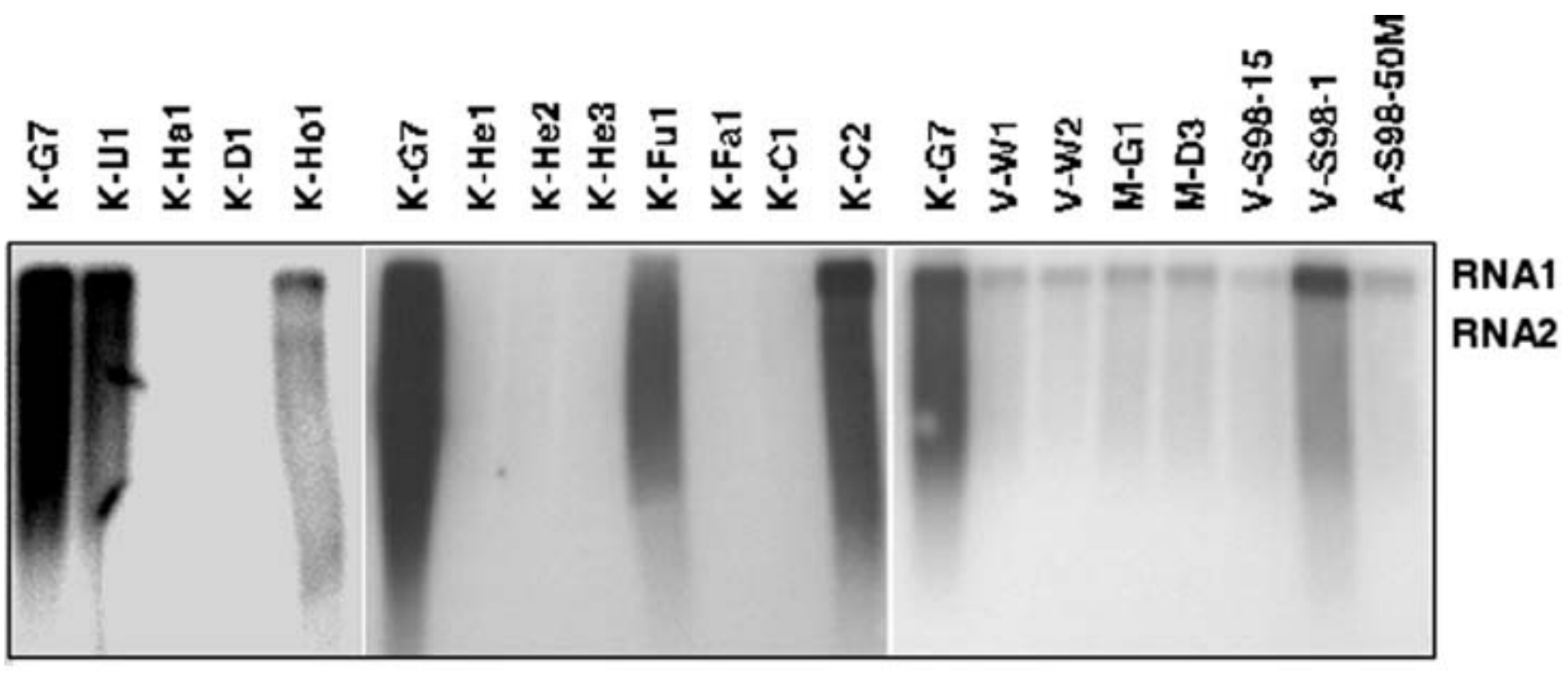

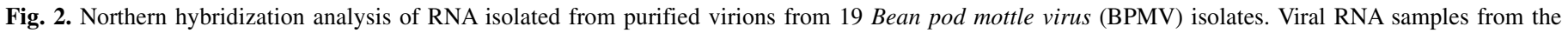

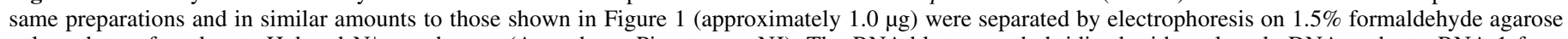

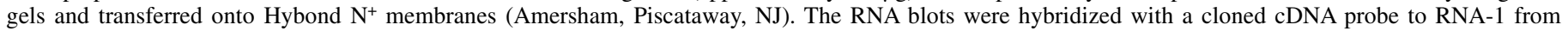
BPMV isolate K-G7. 
contrasts using statistical analysis software (Windows version 6.12, SAS Institute, Cary, NC). Linear contrasts were used to compare inoculated versus noninoculated plots, strain subgroups I and II versus the reassortants, and strain subgroup I versus II.

\section{RESULTS AND DISCUSSION}

Symptomatology. Twenty-one different BPMV isolates were tested for symptom production on soybean cv. Essex (Table 2). The resulting symptoms were scored as follows: severe (severe stunting, yellow mottling, leaf distortion, and extensive blistering), intermediate (yellow/green mottling with some stunting and blistering), and mild (mild green mottling and little or no stunting). All soybean cultivars tested, including Essex, Williams 82, Fayette, Jack, Davis, Clark, York, Dare, and Hutchinson, were susceptible to BPMV infection regardless of the viral isolate used.

All BPMV isolates induced necrotic lesions on Phaseolus vulgaris (L.) cv. Pinto and chlorotic lesions with necrotic centers on P. vulgaris cv. Bountiful. The response of the bean cv. Black Valentine to BPMV varied with the source of seeds. Seedlings germinated from seeds obtained from three commercial sources (Vermont Bean Seed Co., Vaucluse, SC; Sauk River Seed, Albany, MN; and Seeds For The South, Graniteville, SC) showed chlorotic lesions on inoculated leaves without systemic infection. However, 'Black Valentine' bean seedlings, generated from seeds supplied by R. Gergerich (University of Arkansas), produced systemic symptoms similar in severity to those induced by the different isolates on soybean (Table 2). Skotland (25) also reported that 'Black Valentine' seed obtained from four different seed companies yielded plants that were only susceptible to local lesion infection. The original report of Zaumeyer and Thomas (27) on BPMV, however, listed 'Black Valentine' bean as a systemic host. All BPMV isolates tested, except $\mathrm{K}-\mathrm{Hol}$, induced symptomless infections in cowpea. The K-Hol isolate, the most severe on soybeans, produced mild mosaic symptoms on cowpea. Although all BPMV isolates from Kentucky produced chlorotic local lesions on Chenopodium quinoa (Willd.), the majority of those from other states induced ring spots and line patterns on inoculated leaves.

Identification of two distinct subgroups of BPMV strains. Northern hybridization analysis with a cloned cDNA probe to RNA-1 from strain K-G7 indicated that viral RNA-1 from representative BPMV isolates from four states can be separated into at least two distinct hybridization groups (Fig. 2). Because the purpose of the northern hybridization analysis was to ascertain whether RNA from a particular isolate hybridized with the probe, it was necessary in some cases to overexpose the membranes to the X-ray film. Consequently, smears were evident in some of the lanes that hybridized strongly with the probe (Fig. 2). A total of 6 of 19 isolates hybridized strongly with the K-G7 RNA-1 probe, whereas no or very weak hybridization signals were observed with the remaining 13 isolates. Of the six isolates whose RNA-1 hybridized strongly with the K-G7 RNA-1 probe, five were collected from different locations in Kentucky. In contrast, RNA-1 from six of seven isolates tested from other states belonged to a different hybridization subgroup.

The results of northern hybridization analysis (Fig. 2) were reproducible when the same BPMV isolates were subjected to slot

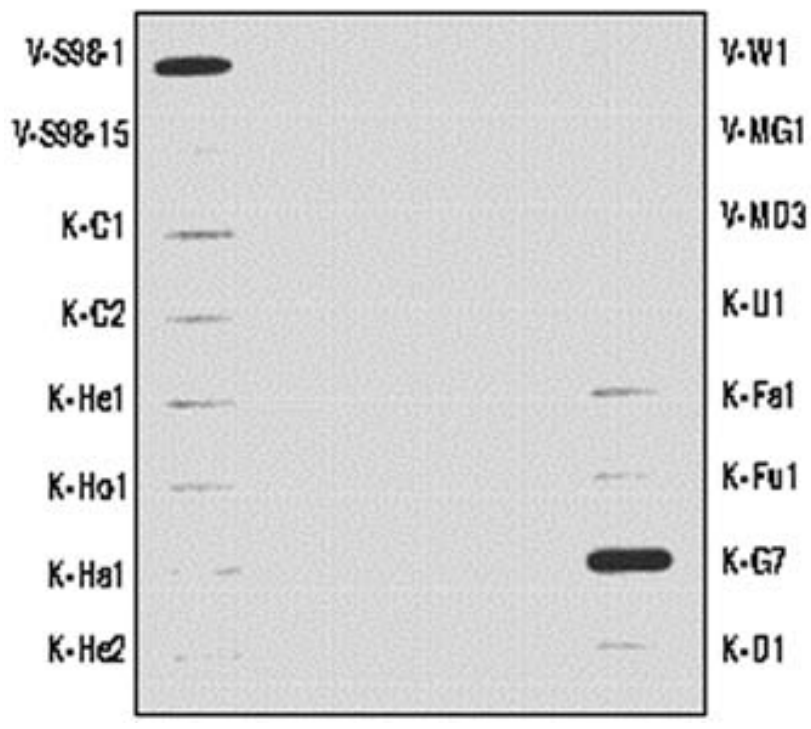

Fig. 4. Slot blot hybridization analysis of RNA isolated from purified virions of 16 Bean pod mottle virus (BPMV) isolates. RNA samples were blotted $\left(200 \mathrm{ng}\right.$ ) onto a Hybond $\mathrm{N}^{+}$membrane (Amersham, Piscataway, NJ) membrane and hybridized with a cloned cDNA probe to RNA-2 from BPMV isolate $\mathrm{K}-\mathrm{G} 7$.

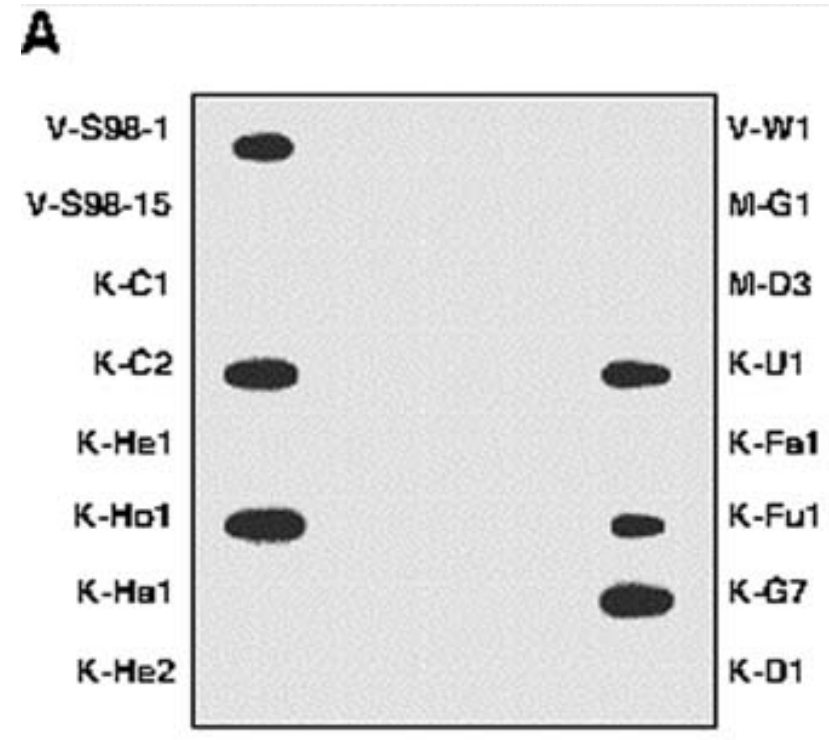

B

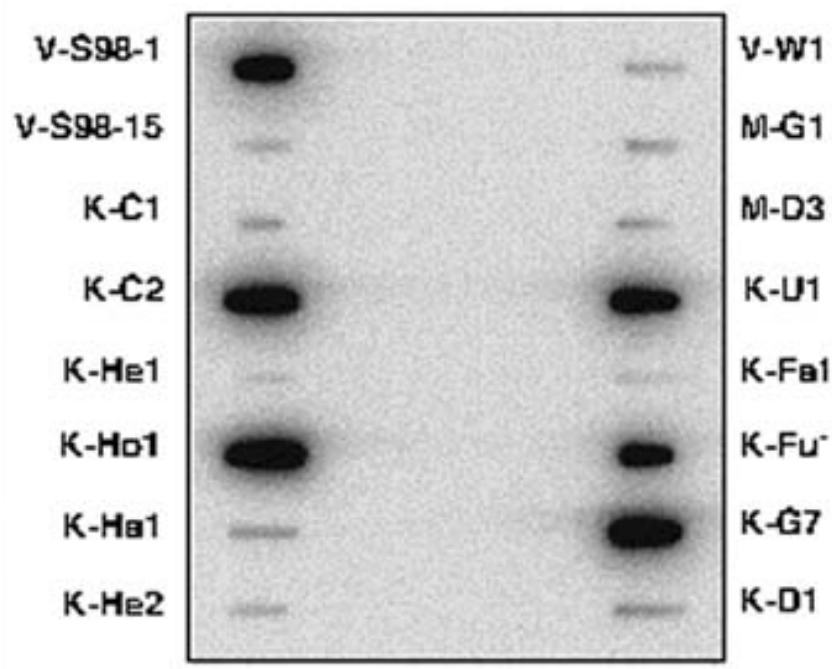

Fig. 3. Slot blot hybridization analysis of RNA isolated from purified virions of 16 Bean pod mottle virus isolates. RNA samples (200 ng) were blotted onto a Hybond $\mathrm{N}^{+}$membrane (Amersham, Piscataway, $\mathrm{NJ}$ ) and hybridized with a cloned cDNA probe to RNA-1 from isolate K-Ho1. A, Membrane was exposed for $2 \mathrm{~h}$ to the phosphorimager screen. B, Same membrane was exposed for $4 \mathrm{~h}$. Note that the $10 \mathrm{RNA}$ samples, which showed no hybridization to the probe (Fig. $3 \mathrm{~A}$ ), exhibited weak hybridization signals after a longer exposure time, thus verifying that all RNA samples were applied to the membrane. 
blot hybridization analysis using cloned cDNA probes to RNA-1 from either strain K-G7 (data not shown) or strain K-Ho1 (Fig. 3A) (same hybridization group as K-G7). Thus, RNA-1 from six isolates hybridized strongly with K-G7 and K-Ho1 RNA-1 probes, whereas the remaining 10 isolates showed no hybridization signals after a short exposure time $(2 \mathrm{~h})$ (Fig. 3A). With a longer exposure of the same membrane to the phosphorimager screen (4 h), comparable weak hybridization signals were detected for all 10 isolates, thus verifying that equivalent amounts of RNA samples were applied to the membrane (Fig. 3B). The high stringency conditions used in our northern and slot blot hybridization experiments require that sequences have at least $90 \%$ identity to the probe in order to generate strong hybridization signals (17). The production of weak or no hybridization signals indicates that the percent identity between RNA-1 from each of the 10 isolates and the RNA-1 probes is less than 90\%. This conclusion is supported by the nucleotide sequencing data of representative isolates of the two hybridization groups.

The biological, molecular, and structural properties of strain KG7 have been well characterized and it is regarded as the type strain of BPMV $(3,4,9,10,16)$. As the type strain with known sequence and to facilitate the classification of our isolates based on nucleic acid hybridization analysis, we designated BPMV K-G7 as the prototype of hybridization subgroup I. We selected strain K-Ha1, which did not hybridize with the K-G7 RNA-1 probe, as a representative of a second hybridization subgroup (designated subgroup II). The complete nucleotide sequences of both genomic RNAs of isolate K-Ha1 were recently determined $(\mathrm{H}$. Gu, C. Zhang, and S. A. Ghabrial, unpublished data) and their sequences deposited in GenBank (Table 1 provides GenBank accession numbers). The values for percent nucleotide sequence identity between strains K-G7 and $\mathrm{K}-\mathrm{Ha} 1$, as determined by sequence comparison using the GAP program, are 85.5 and $86.9 \%$, respectively, for RNA-1 and RNA-2.

Surprisingly, the classification of BPMV isolates into two distinct subgroups based on hybridization with the RNA-1 probes (Figs. 2 and 3A) was not so apparent when a cDNA clone to K-G7 RNA-2 was used as a probe. Only two isolates (V-S98-1 and $\mathrm{K}-\mathrm{G} 7$ ) of the six tentatively classified as belonging to subgroup I (based on hybridization with the RNA-1 probes) hybridized strongly with the K-G7 RNA-2 probe (Fig. 4). Isolates K-C2, $\mathrm{K}-\mathrm{Ho} 1, \mathrm{~K}-\mathrm{U} 1$, and K-Fu1 showed very weak or no hybridization signals and these signals were comparable to signals from the subgroup II isolates.

The results of the reciprocal slot blot hybridization assays using cloned cDNA probes to RNA-1 and RNA-2 from the subgroup II strain K-Hal are shown in Figure 5. Ten of the isolates tested hybridized strongly to the RNA-1 probe from the subgroup II strain, whereas the remaining six isolates, previously classified as belonging to subgroup I, showed little or no hybridization. In contrast, the 14 BPMV isolates that did not react with the subgroup I RNA-2 probe hybridized strongly with subgroup II probe (Fig. 5B versus Fig. 4). The results thus indicate that the genomes of only two isolates out of the 16 tested hybridized solely to subgroup I probes, whereas the genomes of 10 isolates hybridized solely with subgroup II probes. The remaining four isolates (K-C2, K-Ho1, $\mathrm{K}-\mathrm{Fu} 1$, and $\mathrm{K}-\mathrm{U} 1)$ displayed hybridization patterns indicative of

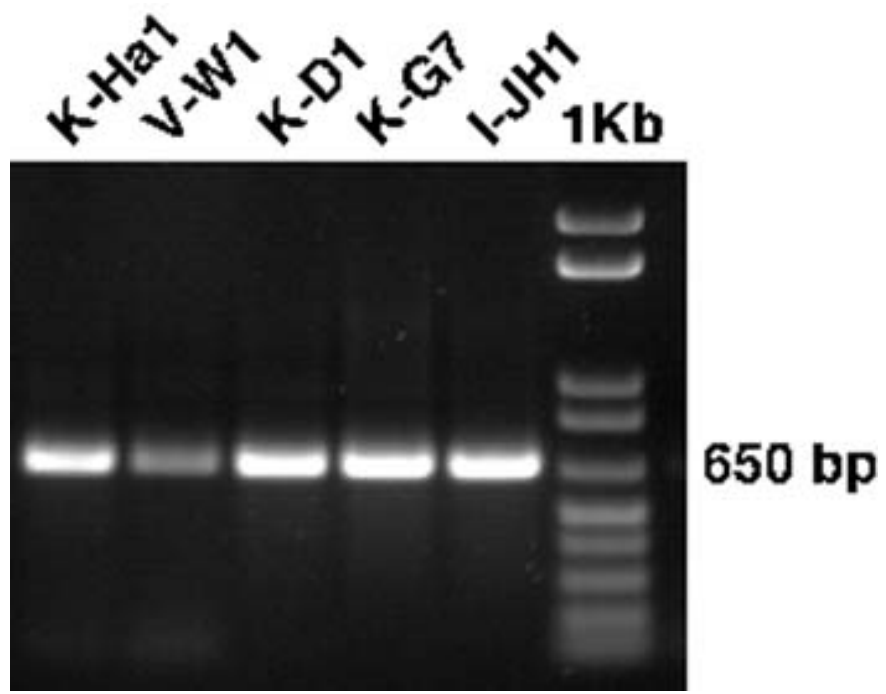

Fig. 6. Reverse transcription-polymerase chain reaction (PCR) analysis of RNA samples from five isolates of Bean pod mottle virus. PCR products generated with RNA samples from isolates K-G7 (subgroup I), K-Ha1, V-W1, K-D-1, and I-JH1 (subgroup II) were electrophoresed on $1 \%$ agarose and stained with ethidium bromide. Lane marked $1 \mathrm{~kb}$ contains $1-\mathrm{kb}$ plus DNA ladder (Gibco BRL, Gaithersburg, MD).
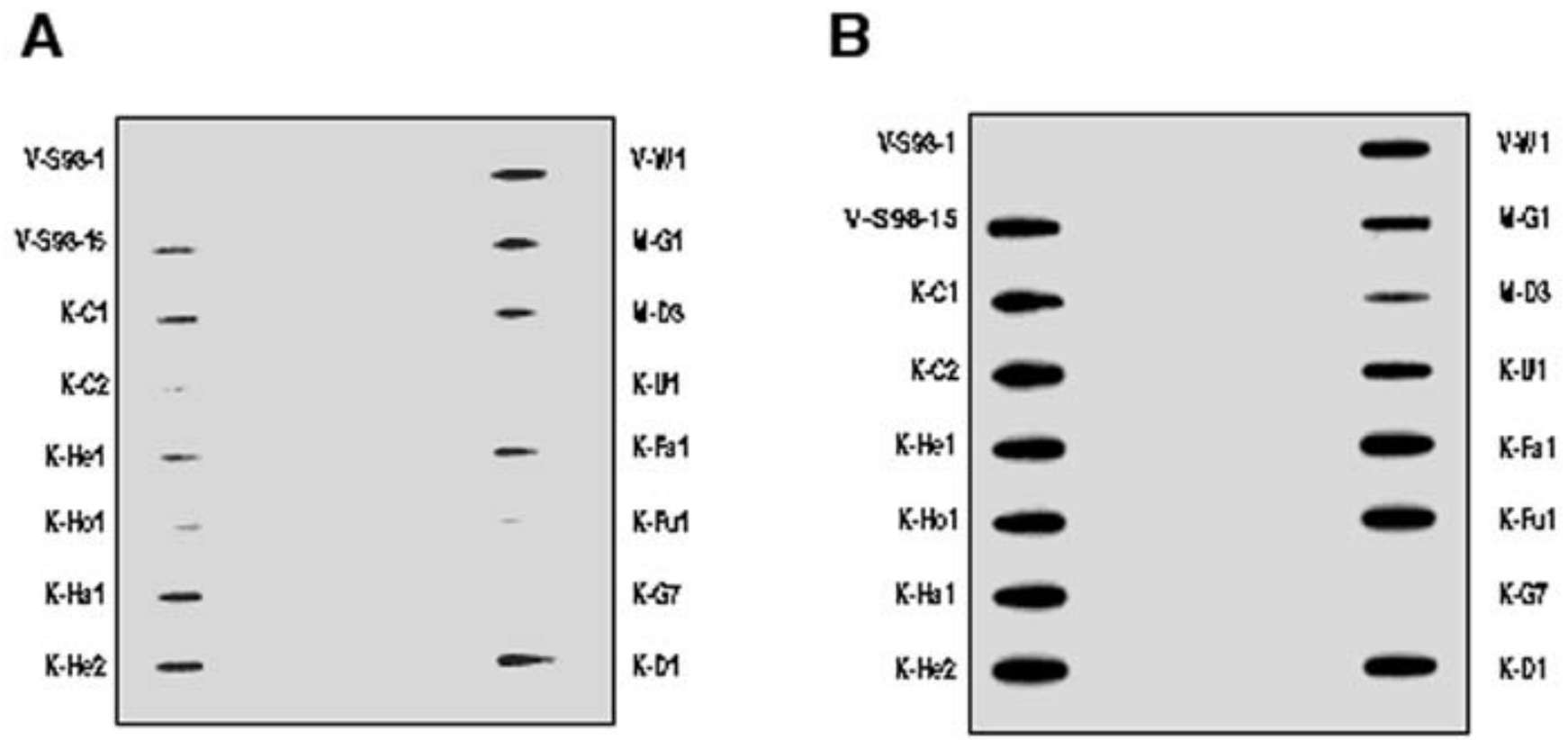

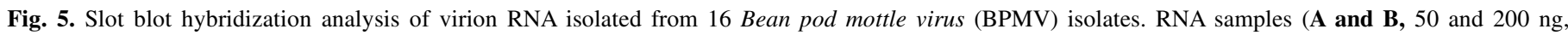

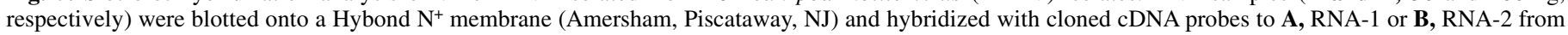
BPMV strain K-Ha1. 
reassortants between the two subgroups, with RNA-1 derived from a subgroup I strain and RNA-2 derived from a subgroup II strain. The reassortant status of strain K-Ho1 was confirmed by nucleotide sequencing of full-length cDNA clones of its genomic RNAs (Table 1 provides GenBank accession numbers) (H. Gu, C. Zhang, and S. A. Ghabrial, unpublished data).

In a study on the diversity of Squash mosaic virus (SqMV), a member of the genus Comovirus, Haudenshield and Palukaitis (13), using northern hybridization analysis with a cDNA probe to RNA-2, classified the SqMV isolates into two hybridization groups. Like BPMV, the SqMV isolates were disproportionately distributed between the two groups. Of the five SqMV isolates tested, one belonged to hybridization group 1, whereas the remaining four were placed in hybridization group 2 (13). Because probes to SqMV RNA-1 probes were not used in that study, it cannot be ruled out that some of the isolates are reassortants. It is clear from the present BPMV study that comovirus reassortments occur in nature, and that the use of cloned probes to both genomic RNAs would be required to unravel the extent of diversity.

It is of interest that the recent increase in BPMV incidence has been concomitant with a large increase in the beetle vector populations as well as with an augmentation in disease symptom severity. Molecular characterization of such severe BPMV isolates revealed that they are reassortants between two distinct subgroups of strains (this study). The BPMV isolates collected in earlier virus surveys in the 1970s and 1980s $(8,9)$ induced only mild or moderate symptoms on soybeans (Table 2) (S. A. Ghabrial, unpublished data). The relatively mild BPMV strain K-G7, the prototype of subgroup I, was isolated in 1975 (8), and the mild isolates included in the present study belonged to subgroup II. The severe reassortant strains thus appear to be of recent occurrence and correlated with the recent large increases in the beetle vector populations and BPMV incidence. Although these severe natural reassortants appear to be stable in the short term, their long survival in nature remains to be seen.

RT-PCR analysis. The occurrence of broad diversity among field isolates of BPMV, as described in the previous section, prompted us to search the known nucleotide sequences of BPMV strains for the presence of highly conserved regions among BPMV strains. The purpose for this search was to develop an RT-PCR assay based on the sequences of such conserved regions so that sensitive and reliable detection of all BPMV isolates might be possible, regardless of the known diversity. We selected a region of $653 \mathrm{bp}$ in the RNA-2 cDNA sequence containing the nucleotides at positions 2070 to 2722 (part of the coding region of BPMV capsid polyprotein). A pair of primers was designed to prime the amplification of the 653-bp fragment using RT-PCR and RNA preparations from purified virions of several BPMV isolates. The results shown in Figure 6 indicate that PCR products of uniform size (653 bp) were generated from all isolates tested. Identical results were also obtained with RNA samples from isolates V-S98-1 (subgroup I), CB-1, and $\mathrm{H}-14$ (reassortant strains collected from Illinois) (S. A. Ghabrial, unpublished data). The PCR products were cloned and sequenced (at least two clones from each of six BPMV isolates were sequenced in both directions) and their nucleotide sequences have been deposited as GenBank Accession Nos. AF330206, AF330207, AF330208, AF330209, AF330210, and AF448497, respectively, for isolates K-D1, K-Ha1, K-Ho1, V-W1, I-JH1, and V-S98-1.

TABLE 3. Comparative yield losses in soybean (Essex and two Essex Soybean mosaic virus-resistant isolines) inoculated with five different isolates of Bean pod mottle virus (BPMV)

\begin{tabular}{lccc}
\hline BPMV isolate & $\begin{array}{c}\text { Strain } \\
\text { subgroup }^{\mathrm{y}}\end{array}$ & $\begin{array}{c}\text { Seed weight } \\
(\mathrm{g} / \mathrm{plot})^{\mathrm{z}}\end{array}$ & $\begin{array}{c}\text { \% Noninoculated } \\
\text { control }\end{array}$ \\
\hline Noninoculated & & $133 \mathrm{a}$ & \\
K-G7 & I & $96 \mathrm{~b}$ & $72 \%$ \\
K-Ha1 & II & $134 \mathrm{a}$ & $100 \%$ \\
K-D1 & II & $98 \mathrm{~b}$ & $74 \%$ \\
K-Ho1 & I/II & $80 \mathrm{~b}$ & $60 \%$ \\
K-U1 & I/II & $105 \mathrm{~b}$ & $79 \%$ \\
\hline
\end{tabular}

${ }^{y}$ Strain subgroup affiliation (I, II, or an assortment I/II) was determined by nucleic acid hybridization analysis (Figs. 2 to 5).

${ }^{\mathrm{z}}$ Means followed by the same letter are not significantly different at $P=0.05$.

\section{Percentage nucleotide/amino acid identity}

\begin{tabular}{|c|c|c|c|c|c|c|c|}
\hline & K-G7 & V-S98-1 & K-Ha1 & K-Ho1 & K-D1 & I-JH1 & V-W1 \\
\hline K-G7 & & 98.3 & 90.4 & 88.7 & 89.7 & 90.2 & 90.0 \\
\hline V-S98-1 & 99.5 & & 90.9 & 89.6 & 90.4 & 90.5 & 90.7 \\
\hline $\mathrm{K}-\mathrm{Ha} 1$ & 99.5 & 100 & & 98.0 & 98.2 & 98.6 & 97.9 \\
\hline $\mathrm{K}-\mathrm{Ho} 1$ & 99.5 & 100 & 100 & & 97.1 & 97.6 & 96.8 \\
\hline K-D1 & 99.1 & 99.5 & 99.5 & 99.5 & & 98.6 & 97.9 \\
\hline I-JH1 & 99.5 & 100 & 100 & 100 & 99.5 & & 98.3 \\
\hline V-W1 & 98.6 & 99.1 & 99.1 & 99.1 & 98.6 & 99.5 & \\
\hline
\end{tabular}

Fig. 7. Percent nucleotide (and deduced amino acid) sequence identity of a 653-bp RNA-2 cDNA fragment between different Bean pod mottle virus isolates. Values for the nucleotide sequence identity scores (above diagonal) and deduced amino acid identity scores (below diagonal) were calculated by the GAP program of the University of Wisconsin Genetics Computer Group package. The nucleotide sequence data for the 653-bp cDNA fragments from K-G7, K-Ho1, K-Ha1, K-D1, I- JH1, V-W1, and V-S98-1 are deposited as GenBank Accession Nos. M62738, AF330208, AF330207, AF330206, AF330210, AF330209, and AF448497, respectively. 
The percent nucleotide sequence identity of the 653-bp RNA-2 cDNA fragment between isolates within the same strain subgroup varied from 97.1 to $98.6 \%$, whereas the corresponding values for isolates in different subgroups were 88.7 to $90.9 \%$ (Fig. 7). On the other hand, the values for percent deduced amino acid sequence identity between the capsid polyprotein fragments (encoded by the 653-bp fragment) from the various BPMV isolates were similar to each other (98.6 to $100 \%)$, regardless of whether the isolates were in the same or in different subgroups (Fig. 7). These results suggest that the amino acid sequence of the capsid polyprotein is strictly conserved among BPMV isolates. The conclusion that the amino acid sequences of the capsid polyproteins from distinct BPMV isolates (based on nucleic acid hybridization assays) are highly conserved was also supported by the results of western blot analysis. All BPMV isolates tested reacted strongly with an antiserum against BPMV K-G7 virions (subgroup I), regardless of their strain classification (data not shown).

Field plot experiments. No significant differences $(F=0.8)$ in the yield of the three Essex isolines were detected (Essex, $104 \mathrm{~g}$

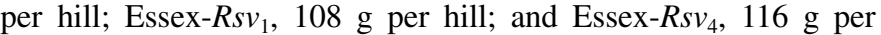
hill). The interaction of isoline-virus isolate was also nonsignificant $(F=0.64)$. Thus, the SMV resistance alleles $R s v_{1}$ and $R s v_{4}$ did not provide resistance to BPMV. Although all inoculated plants showed virus symptoms, the various BPMV isolates differed in symptom severity and the magnitude of yield loss that they caused (Table 3 ). The greatest yield loss was due to infection with the reassortant strain K-Ho1, which induced the most severe symptoms. The plants in noninoculated plots (133 g per plot) yielded significantly more than the plants in inoculated plots (103 g per plot; $F=9.05, P \leq 0.01$ ). Yield reductions caused by the different strain subgroups (I, II, and the reassortants I/II) were not significantly different (strains versus reassortants; $F=3.10$, strain subgroup I versus II; $F=2.59$ ). The number of isolates tested, however, was limited and only one isolate from strain subgroup I was included in the study. Large differences in yield reductions were observed within a strain subgroup. K-D1 reduced yield significantly more than strain K-Ha1, both in strain subgroup II. This is of interest because K-D1 was considered a mild isolate under greenhouse conditions but induced relatively more severe symptoms under field conditions. All other isolates induced symptoms similar to those described under greenhouse conditions.

In summary, the data presented in this study represents, to our knowledge, the first report on strain diversity among BPMV isolates. Nucleic acid hybridization analysis and nucleotide sequencing data clearly revealed the occurrence in nature of two distinct subgroups of BPMV strains as well as reassortants between the two subgroups. The nucleotide and deduced amino acid sequence analyses of the entire genomes of three BPMV strains indicated that the coding sequence of the capsid polyprotein is more highly conserved among BPMV isolates than the remainder of the genome. This finding was supported by the results from our RT-PCR and western blot analyses. In a field plot experiment, different BPMV isolates induced symptoms on soybeans that varied in severity and in the incurred yield losses. There was, however, no relationship between the magnitude of yield loss and strain classification. Knowledge of strain diversity among BPMV isolates is necessary to ensure that selected or newly developed soybean germ plasms may offer broad protection against the full range of BPMV strains found in nature. This is of special importance in view of the recent increase of BPMV incidence in the major soybean-growing regions in the United States.

\section{ACKNOWLEDGMENTS}

This research was primarily supported with grant 8212 from The United Soybean Board. This paper (01-12-96) is published with the approval of the Director of the Kentucky Agricultural Experiment Station. We thank W. Havens for technical support and A. Crume for greenhouse care.

\section{LITERATURE CITED}

1. Anjos, J. R., Jarlfors, U., and Ghabrial, S. A. 1992. Soybean mosaic potyvirus enhances the titer of two comoviruses in dually infected soybean plants. Phytopathology 82:1022-1027.

2. Calvert, L. A., and Ghabrial, S. A. 1983. Enhancement by soybean mosaic virus of bean pod mottle virus titer in doubly infected soybean. Phytopathology 73:992-997.

3. Chen, Z., Stauffacher, C., Li, Y., Schmidt, T., Bomu, W., Kamer, G., Shanks, M., Lomonossoff, G., and Johnson, J. E. 1989. Protein-RNA interactions in an icosahedral virus at $3.0 \AA$ resolution. Science 245: 154-159.

4. Di, R., Hu, C.-C., and Ghabrial, S. A. 1999. Complete nucleotide sequence of bean pod mottle virus RNA1: Sequence comparisons and evolutionary relationships to other comoviruses. Virus Genes 18:129-137.

5. Di, R., Purcell, V., Collins, G. B., and Ghabrial, S. A. 1996. Production of transgenic soybean lines expressing the bean pod mottle virus coat protein precursor gene. Plant Cell Rep. 15:746-750.

6. Fehr, W. R., Caviness, C. E., Burmood, D. T., and Pennington, J. S. 1971. Stages of development descriptions for soybeans, Glycine max (L.) Merr. Crop Sci. 11:929-931.

7. Gergerich, R. C., and Scott, H. A. 1996. Comoviruses: Transmission, epidemiology, and control. Pages 77-98 in: The Plant Viruses 5: Polyhedral Virions and Bipartite RNA Genomes. B. D. Harrison and A. F. Murant, eds. Plenum Press, New York.

8. Ghabrial, S. A., Hershman, D. E., Johnson, D. W., and Yan, D. 1990. Distribution of bean pod mottle virus in soybeans in Kentucky. Plant Dis. 74:132-134.

9. Ghabrial, S. A., Pickard, C. M., and Stuckey, R. E. 1977. Identification and distribution of virus diseases of soybean in Kentucky. Plant Dis. Rep. 61:690-694.

10. Ghabrial, S. A., and Schultz, F. J. 1983. Serological detection of bean pod mottle virus in bean leaf beetles. Phytopathology 73:480-483.

11. Goldbach, R., Martelli, G. P., and Milne, R. G. 1995. Family Comoviridae. Pages 341-347 in: Virus Taxonomy. F. A. Murphy, C. M. Fauquet, D. H. L. Bishop, S. A. Ghabrial, A. W. Jarvis, G. P. Martelli, M. A. Mayo, and M. D. Summers, eds. Springer-Verlag, New York.

12. Hartman, G. L., Sinclair, J. B., and Rupe, J. C. 1999. Bean pod mottle virus. Pages 61-62 in: Compendium of Soybean Diseases. 4th ed. The American Phytopathological Society, St. Paul, MN.

13. Haudenshield, J. S., and Palukaitis, P. 1998. Diversity among isolates of squash mosaic virus. J. Gen. Virol. 79:2331-2341.

14. Laemmli, U. K. 1970. Cleavage of structural proteins during the assembly of the head of bacteriophage T4. Nature 227:680-685.

15. Lomonossoff, G. P., and Ghabrial, S. A. 2001. Comoviruses. Pages 239242 in: Encyclopedia of Plant Pathology, Vol. 1. O. C. Maloy and T. D. Murray, eds. John Wiley \& Sons, New York.

16. MacFarlane, S. A., Shanks, M., Davies, J. W., Zlotnick, A., and Lomonossoff, G. P. 1991. Analysis of the nucleotide sequence of bean pod mottle virus middle component RNA. Virology 183:405-409.

17. Memelink, J., Swords, K. M. M., Staehelin, L. A., and Hoge, J. H. C. 1994. Southern, Northern and Western blot analysis. Pages 1-23 in: Plant Molecular Biology Manual. 2nd ed. S. B. Gelvin and R. A. Schilperoort, eds. Kluwer Academic Publishers, London.

18. Peden, K. W. C., and Symons, R. H. 1973. Cucumber mosaic virus contains a functionally divided genome. Virology 155:487-492.

19. Reddy, M. S. S., Ghabrial, S. A., Redmond, C. T., Dinkins, R. D., and Collins, G. B. 2001. Resistance to Bean pod mottle virus in transgenic soybean lines expressing the capsid polyprotein. Phytopathology 91: 831-838.

20. Ross, J. P. 1963. Transmission of bean pod mottle virus in soybean by beetles. Plant Dis. Rep. 47:1044-1050.

21. Ross, J. P. 1968. Effect of single and double infections of soybean mosaic and bean pod mottle viruses on soybean yield and seed characters. Plant Dis. Rep. 52:344-348.

22. Ross, J. P., and Butler, A. K. 1985. Distribution of bean pod mottle virus in soybeans in North Carolina. Plant Dis. 69:101-103.

23. Sambrook, J., and Russell, D. W. 2001. Molecular Cloning: A Laboratory Manual. 3rd ed. Cold Spring Harbor Laboratory, Cold Spring Harbor, NY.

24. Schmitthenner, A. F., and Kmetz, K. 1980. Role of Phomopsis spp. in the soybean seed rot problem. Pages 355-366 in: Proc. World Soybean Res. Conf., 2nd. Westview Press, Boulder, CO.

25. Skotland, C. B. 1958. Bean pod mottle virus of soybeans. Plant Dis. Rep. 42:1155-1156.

26. Stuckey, R. E., Ghabrial, S. A., and Reicosky, D. A. 1982. Increased incidence of Phomopsis spp. in seeds from soybean infected with bean pod mottle virus. Plant Dis. 66:826-829.

27. Zaumeyer, W. J., and Thomas, H. R. 1948. Pod mottle, a virus disease of beans. J. Agric. Res. 77:81-96. 